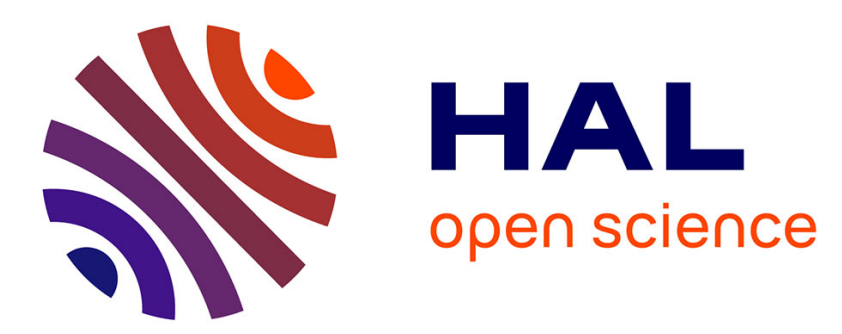

\title{
Inhibition activity of wild berry juice fractions against Streptococcus pneumoniae binding to human bronchial cells
}

\author{
Sanna Huttunen, Marko Toivanen, Satu Arkko, Marika Ruponen, Carina \\ Tikkanen-Kaukanen
}

\section{To cite this version:}

Sanna Huttunen, Marko Toivanen, Satu Arkko, Marika Ruponen, Carina Tikkanen-Kaukanen. Inhibition activity of wild berry juice fractions against Streptococcus pneumoniae binding to human bronchial cells. Phytotherapy Research, 2010, 25 (1), pp.122. 10.1002/ptr.3240 . hal-00599830

\section{HAL Id: hal-00599830 https://hal.science/hal-00599830}

Submitted on 11 Jun 2011

HAL is a multi-disciplinary open access archive for the deposit and dissemination of scientific research documents, whether they are published or not. The documents may come from teaching and research institutions in France or abroad, or from public or private research centers.
L'archive ouverte pluridisciplinaire HAL, est destinée au dépôt et à la diffusion de documents scientifiques de niveau recherche, publiés ou non, émanant des établissements d'enseignement et de recherche français ou étrangers, des laboratoires publics ou privés. 
Inhibition activity of wild berry juice fractions against Streptococcus pneumoniae binding to human bronchial cells

\begin{tabular}{|r|l|}
\hline Journal: & Phytotherapy Research \\
\hline Manuscript ID: & PTR-10-0045.R2 \\
\hline Wiley - Manuscript type: & Full Paper \\
\hline Author: & 12-May-2010 \\
\hline & $\begin{array}{l}\text { Complete List of Authors: } \\
\text { Tuttunen, Sanna; University of Eastern Finland, Institute of Public } \\
\text { Toivanen, Marko; University of Eastern Finland, School of Pharmacy } \\
\text { Ruponen, Marika; University of Eastern Finland, School of Pharmacy } \\
\text { Tikkanen-Kaukanen, Carina; University of Eastern Finland, Institute } \\
\text { of Public Health and Clinical Nutrition }\end{array}$ \\
\hline Keyword: & $\begin{array}{l}\text { Streptococcus pneumoniae, berries, anti-adhesion, antimicrobial, } \\
\text { Calu-3 }\end{array}$ \\
\hline
\end{tabular}

\section{(4) ScholarONE" \\ Manuscript Central}




\section{Inhibition activity of wild berry juice fractions against Streptococcus}

\section{2 pneumoniae binding to human bronchial cells}

3

4 Sanna Huttunen ${ }^{1 *}$, Marko Toivanen ${ }^{2}$, Satu Arkko², Marika Ruponen ${ }^{2}$ \& Carina 5 Tikkanen-Kaukanen ${ }^{1}$

6

$7{ }^{1}$ Institute of Public Health and Clinical Nutrition, ${ }^{2}$ School of Pharmacy, Faculty of 8 Health Sciences, University of Eastern Finland, Kuopio Campus, P.O.Box 1627, FI970211 Kuopio, Finland

$11{ }^{*}$ Correspondence to: Sanna Huttunen, Institute of Public health and Clinical Nutrition, 12 Faculty of Health Sciences, University of Eastern Finland, Kuopio Campus, P.O.Box 13 1627, FI-70211 Kuopio, Finland. E-mail: sanna.huttunen@uef.fi; Tel. +358-4014 3552962; fax. +358-17-162936

15

16 Contract/ grant sponsor: the European Regional Development Fund; Contract/ grant 17 sponsor: the Finnish Funding Agency for Technology and Innovation (TEKES), 18 contract/ grant number: 70031/06; Contract/ grant sponsor: the Academy of Finland

20 Short title: berry juices against pneumococcal adherence 


\section{ABSTRACT}

22 Bacterial adhesion to the cell surface is a crucial step before infection can take place.

23 Inhibition of bacterial binding offers a novel preventive approach against infections.

24 Cranberry (Vaccinium macrocarpon Ait.) juice has been found to have anti-adhesive

25 activity against different bacteria. Streptococcus pneumoniae is an important pathogen and the most common cause for pneumonia, meningitis, and otitis media. In this study the inhibitory activity of cranberry (Vaccinium oxycoccos L.), bilberry (Vaccinium myrtillus L.), and crowberry (Empetrum nigrum and Empetrum hermaphroditum L.) juice fractions against pneumococcal binding was tested using human bronchial cells (Calu-3) as an adhesion model. In addition, antimicrobial activity of the berry juice fractions was tested. It was found that the studied berry juice fractions had anti-adhesion activity and cranberry juice was the most active. The adhesion inhibition activity of cranberry juice was nearly $90 \%$ at the concentration of $8.7 \mathrm{mg} / \mathrm{g}$ of soluble solids. Antimicrobial activity of the studied berry juice fractions was found to be remarkable; pneumococcal growth was inhibited totally at the concentration of $\sim 86 \mathrm{mg} / \mathrm{g}$. Both antiadhesion and antimicrobial activities were reduced after solid-phase extraction of the berry juices, which may suggest molecular synergistic effects of the berry juice molecules against $S$. pneumoniae. The findings indicate that cranberry, bilberry, and crowberry juices have potential against pneumococcal infections.

Keywords: Streptococcus pneumoniae, berries, anti-adhesion, antimicrobial, Calu-3 


\section{INTRODUCTION}

44 Streptococcus pneumoniae is an important human pathogen and the most common cause for pneumonia, meningitis, and otitis media (Feldman and Anderson, 2009). It is estimated that up to $60 \%$ of the population in the world carry the pneumococcus

47 in the nasopharynx (Mitchell, 2003). Nasopharyngeal colonisation is mostly asymptomatic and it has a key role in pneumococcal disease and spread (Bogaert et al., 2004). Pneumococcal infection is the cause of death for more than 1 million children in the world per year, most of them in developing countries (Kadioglu et al., 2008). Risk factors for pneumococcal diseases include extremes of age, immunodeficiency (Bogaert et al., 2004), as well as health habits and life style

53 factors such as smoking and contact with pets (Almirall et al., 2008).

54 There is a vaccine available against $S$. pneumoniae. The pneumococcal vaccine is 55 targeted against the capsular polysaccharide of $S$. pneumoniae. This 23-valent 56 vaccine has a theoretical coverage of $90 \%$ of disease causing serotypes. For young 57 children a 7-valent capsular polysaccharide-protein conjugate vaccine is used due to 58 weak response to polysaccharide vaccination (Bogaert et al., 2004). High costs of the 59 conjugate vaccine reduce its use in developing countries, where the need for 60 prevention of pneumococcal diseases is most urgent (Kadioglu et al., 2008). 61 Antibiotics of different classes, e.g. $\beta$-lactams, macrolides, aminoglycosides, and

62 fluoroquinolines, are used against pneumococcal infections (Woodhead et al., 2005).

63 However, antibiotic resistance to various classes of antibiotics has made the 64 treatment of pneumococcal infections even more difficult (Feldman and Anderson, 65 2009). 
66 Due to resistance and vaccination insufficiency it is important to find alternative means

67 against pneumococcal diseases. Anti-adhesion therapy is a novel approach in preventing

68

69 bacterial infections (Ofek et al., 2003). In anti-adhesion therapy the important interaction between the pathogen and host cell is inhibited by soluble carbohydrates or their analogs (Ofek et al., 2003; Zopf and Roth, 1996). Since anti-adhesion agents are aimed to interfere only with the bacterial attachment and they do not kill the pathogens, resistance towards these inhibitors is likely to evolve slowly (Joosten et al., 2004). Results from animal experiments show that soluble carbohydrates can protect against experimental pneumococcal pneumonia (Idänpään-Heikkilä et al., 1997).

Berries and their health effects have gained a lot of attention in recent years, and their anti-adhesion potential is an interesting field of research. Anti-adhesive properties of cultivated American cranberry (Vaccinium macrocarpon Ait.) have been studied widely and anti-adhesive activity has been found against different bacteria (Burger et al., 2000; Howell et al., 1998; Weiss et al., 2002). We have discovered anti-adhesion activity of wild cranberry (Vaccinium oxycoccos L.), bilberry (Vaccinium myrtillus L.), lingonberry (Vaccinium vitis-idaea L.), and crowberry (Empetrum nigrum and hermaphroditum L.) juice fractions against the serious human pathogen Neisseria meningitidis (Toivanen et al., 2009). In addition, our studies have demonstrated berry and berry juice binding activity of Streptococcus agalactiae, and hemagglutination inhibition activity against Streptococcus suis (Toivanen et al., 2010). We have found as well that $S$. pneumoniae has binding activity to low molecular size fractions of bilberry (Vaccinium myrtillus L.) and cranberry (Vaccinium oxycoccos L.) juices in a microtiter well assay (Toivanen et al., 2010). In the present study we investigated the antiadhesion activity, or binding inhibition activity of low molecular size fractions and 
90 subfractions from bilberry (Vaccinium myrtillus L.), cranberry (Vaccinium oxycoccos

91

92

L.), and crowberry (Empetrum nigrum and hermaphroditum L.) juices against $S$. pneumoniae. Adhesion and anti-adhesion experiments were conducted using Calu-3 cells (human bronchial epithelial cell line) as a model for adhesion. In addition, antimicrobial activity of the studied berry juice fractions was tested.

\section{MATERIALS AND METHODS}

Berry Juices. Bilberry (Vaccinium myrtillus L.), cranberry (Vaccinium oxycoccos L.), and crowberry (Empetrum nigrum and Empetrum hermaphroditum L.) (65 ${ }^{\circ}$ Brix, content of soluble solids $\mathrm{g} / 100 \mathrm{~g}$ of solution) juice concentrates were purchased from Kiantama Ltd (Suomussalmi, Finland). Juice concentrate of apple (mix of cultivars) (70 ${ }^{\circ}$ Brix) was purchased from VIP-Juicemaker Ltd (Kuopio, Finland). Additive-free juice concentrates were stored at $-20^{\circ} \mathrm{C}$.

Preparation of Berry Juice Molecular Size Fractions. Berry juice concentrates were diluted with water (1:4) and fractionated into three different molecular size fractions as described before (Toivanen et al., 2009). Briefly, $15 \mathrm{~mL}$ of berry juice was loaded onto a 100 kDa cut-off Biomax Ultrafree-15 filter device (Millipore Corporation, MA, USA) and centrifuged $\left(2000 \mathrm{~g}\right.$ at $\left.4^{\circ} \mathrm{C}\right)$ until the volume was $1.5 \mathrm{~mL}$. Top fraction $(>100 \mathrm{kDa})$ was collected and stored at $-20^{\circ} \mathrm{C}$. The filtrate was loaded onto a $10 \mathrm{kDa}$ cut-off Biomax Ultrafree-15 centrifugal filter device (Millipore Corporation, MA, USA) and centrifuged as described above. Both the top fraction $(10-100 \mathrm{kDa})$ and filtrate $(<10$ $\mathrm{kDa}$, referred here as FI) were stored at $-20^{\circ} \mathrm{C}$. The content of soluble solids in the FI fractions $(\mathrm{mg} / \mathrm{g})$ was analyzed by determining the ${ }^{\circ}$ Brix values by using a refractometer (ATAGO NAR-IT, Tokyo, Japan). FI fractions of cranberry, bilberry, and crowberry were chosen for the present study according to our previous results, where 
114 pneumococcal binding activity was detected to FI fractions of cranberry, bilberry, and 115 crowberry (Toivanen et al., 2010). These berry juice FI fractions composed mostly of 116 sugars and small amounts of small size phenolics (Toivanen et al., 2009; Toivanen et 117 al., 2010).

119 Solid-Phase Extraction (SPE) Subfractionation of Berry Juice FI Fractions. In 120 order to isolate phenolic compounds from the berry juice FI fractions for activity 121 testing, the subfractionation method previously described was used (Toivanen et al., 122 2009). Briefly, the FI fraction of berry juice (3 mL) was mixed with phosphate buffer 123 (pH 7.0) (J. T. Baker, Deventer, The Netherlands) at 1:1 ratio (v/v), and passed through 124 a C-18 SPE cartridge (Waters Corp., Milford, MA; cartridges of $3 \mathrm{~cm}^{3}$ capacity filled 125 with $500 \mathrm{mg}$ of adsorbent). The cartridge was conditioned with $15 \mathrm{~mL}$ of methanol (HPLC grade) (VWR International Ltd., Leuven, Belgium) and equilibrated with $5 \mathrm{~mL}$

127 of $\mathrm{pH} 7.0$ phosphate buffer. After washing with $5 \mathrm{~mL}$ of diluted phosphate buffer $(1: 8$, $128 \mathrm{v} / \mathrm{v}$, with water) and with $5 \mathrm{~mL}$ of water (purified on a Millipore Milli-Q apparatus, 129 Molsheim, France) the cartridge was dried under vacuum for $30 \mathrm{sec}$. Then the elution 130 with $5 \mathrm{~mL}$ of ethyl acetate (Laboratory-Scan, Dublin, Ireland) was performed. The 131 cartridge was dried again under vacuum for $30 \mathrm{sec}$ before the next elution with $3 \mathrm{~mL}$ of 132 water. After that, the elution with $3 \mathrm{~mL}$ of $10 \%$ aqueous methanol was discarded and 133 the ones with $3 \mathrm{~mL}$ of $20 \%$ and $3 \mathrm{~mL}$ of $60 \%$ aqueous methanol were collected 134 separately. Solvents in the subfractions were evaporated by a rotary evaporator at +30 $135{ }^{\circ} \mathrm{C}$. Finally, the solids were reconstituted with water to the concentration of 0.5 or 1.0 136 $\mathrm{mg} / \mathrm{mL}$. Subfractions eluted with water containing phenolic components according to 
137 the methodology employed (Toivanen et al., 2009; Sun et al., 2006) were chosen for the 138 experiments.

139 Cell Culture. The human bronchial epithelial cell line (Calu-3) was a kind gift from 140 Professor Jouni Hirvonen (University of Helsinki, Finland), and it was used between 141 passages 28 and 45. Cells were cultured in Eagle's Minimum Essential Medium 142 (BioWhittaker, Cambrex, Verviers, Belgium) (10 \% v/v) supplemented with heat 143 inactivated fetal bovine serum (Gibco, Paisley, U.K) (10-20 \% v/v), L-glutamine 100x 144 (Euroclone, Pero, Italy) (1\% v/v), non-essential amino acid solution 100x (Euroclone, 145 Pero, Italy) (1 \% v/v), sodium pyruvate (BioWhittaker, Cambrex, Verviers, Belgium) (1 $146 \% \mathrm{v} / \mathrm{v})$, penicillin-streptomycin 100x (Euroclone, Pero, Italy) $(1 \% \mathrm{v} / \mathrm{v})$ and $\mathrm{NaHCO}_{3}$ 147 (Merck, Darmstadt, Germany) $(0.15 \% \mathrm{w} / \mathrm{v})$. Cells were cultivated in $75 \mathrm{~cm}^{2}$ flasks 148 containing $10-20 \mathrm{~mL}$ medium and maintained in a humidified $5 \% \mathrm{CO}_{2}-95 \%$ 149 atmospheric air incubator at $37{ }^{\circ} \mathrm{C}$. The culture medium was changed every 2-3 days 150 and cells were passaged once or twice per week at a 1:2-1:5 split ratio using trypsin151 EDTA solution (Gibco, Paisley, UK).

152 Bacterial Strain and Culture Conditions. Streptococcus pneumoniae clinical strain 153 SB 53845 (isolated from lung) was received from Sauli Haataja (University of Turku, 154 Finland). Bacteria were cultivated at $37{ }^{\circ} \mathrm{C}$ for $18 \mathrm{~h}$ on sheep blood agar plates 155 (Microbiological Laboratory, Kuopio University Hospital, Finland or Labema Inc., 156 Kerava, Finland). An atmosphere of increased $\mathrm{CO}_{2}$ was provided for optimal growth by 157 using a candle-extinction jar (Weiser et al., 1994).

158 Isolation of $S$. pneumoniae. S. pneumoniae were harvested from ten plates and 159 suspended in $40 \mathrm{~mL}$ of sterile PBS (Gibco, Paisley, U.K.) at $0{ }^{\circ} \mathrm{C}$. The suspension was 160 centrifuged at $2000 \mathrm{~g}$ at $4{ }^{\circ} \mathrm{C}$ for $10 \mathrm{~min}$ and washed three times with cold sterile PBS. 
161 The density of the bacterial suspension was standardized to absorbance value of 0.420 at $162 \mathrm{~A}_{600}$. After the last washing, bacteria were suspended to prewarmed $\left(37^{\circ} \mathrm{C}\right)$ Eagle's 163 Minimum Essential Medium and diluted to the density of $10^{8} / \mathrm{mL}$.

164 Binding of S. pneumoniae to Calu-3 Cells. A previously described method (Rytkönen 165 et al., 2004; Todoriki et al., 2001) was used with modifications. Calu-3 cells were seeded on 6-well plates with the cell density of $10^{5}$ per well $20-24$ hours before the experiment, and were let grown into confluence. A culture medium without antibiotics was used. Diluted bacterial suspension $(1.5 \mathrm{~mL})$ prepared as described above was incubated over the cells for one hour at $37{ }^{\circ} \mathrm{C}$. Nonadherent bacteria were removed by 170 three washings with sterile PBS and the infected cells were detached with $0.5 \mathrm{~mL}$ of trypsin-EDTA solution. Infected cells were diluted and appropriate dilutions were plated $(100 \mu \mathrm{l})$ on the sheep blood agar plates and bacteria were cultivated overnight at $37^{\circ} \mathrm{C}$ in a $\mathrm{CO}_{2}$ atmosphere. Attachment of bacteria to Calu-3 cells was determined from duplicate cultures on sheep blood agar plates. Colony forming units (CFU) were counted next day.

176 Inhibition of the Binding of S. pneumoniae to Calu-3 Cells. The assay was done as 177 described above for binding, with the exception that $1.5 \mathrm{~mL}$ of berry juice FI fractions or berry juice subfractions diluted with culture medium (without antibiotics) were incubated over Calu-3 cells for one hour at $37^{\circ} \mathrm{C}$. After incubation with the berry juice 180 fractions or subfractions, the bacterial suspension was added. Tested concentrations for 181 the FI fractions and subfractions were $1.6-9.0 \mathrm{mg} / \mathrm{g}$ of soluble solids and $1-50 \mu \mathrm{g} / \mathrm{mL}$, respectively. Colony forming units were counted next day and the binding inhibition activity was calculated as follows: 
185

186

187

188

189

190

191

192

193

194

195

196

197

198

199

200

201

202

203

204

205

206

207

208

209

210

\section{CFU control - CFU sample}

CFU control $\times 100 \%$

Antimicrobial Assay on Microtiter Plates. Antimicrobial activities of the berry juice F1 fractions and subfractions were tested against S. pneumoniae. According to literature, a microtiter broth microdilution method is most preferable for testing antimicrobial activity of plant material (King et al., 2008). In this study, a previously described method (Amsterdam 2005) was used with modifications. Overnight platecultured S. pneumoniae bacteria were suspended in cold sterile PBS to an optical density of 0.420 at $600 \mathrm{~nm}$. The corresponding colony forming unit was $10^{8}$. Diluted bacterial suspension $(50 \mu \mathrm{L})$ and different concentrations of diluted FI fractions and subfractions $(50 \mu \mathrm{L})$ were incubated in a microtiter plate (Falcon Flexible Plate, Becton Dickinson Labware, NJ, USA) at $37{ }^{\circ} \mathrm{C}$, in $\mathrm{CO}_{2}$ atmosphere for one hour. As a control, bacteria were incubated in the absence of berry juice samples or with Ampicillin (100 $\mu \mathrm{g} / \mathrm{mL})$. The antimicrobial activity of FI fractions and subfractions was analyzed by plating the incubation mixtures in triplicate on sheep blood agar plates. The surviving colony forming units were counted next day. Bacterial survival was calculated by comparing the colony forming units $(\mathrm{CFU})$ of bacteria-sample -mixture and control bacteria:

\section{CFU sample}

CFU control $\times 100 \%$

Statistical Analysis. Results for adhesion inhibition and antimicrobial tests were reported as means \pm standard error of the mean (SEM). Two-tailed, unpaired Student's t-test (Microsoft Excel 2007) was used to calculate the significance of the differences between CFUs from pneumococcal adhesion (control) and pneumococcal adhesion 
211 inhibition; and differences between CFUs from pneumococcal control and

212 pneumococcal-berry incubation mixtures. Significance was defined as a $P$ of $<0.05$.

213 RESULTS AND DISCUSSION

214 Inhibition of the Binding of S. pneumoniae to Calu-3 Cells. Carbohydrate receptors

215 in human airway mediate the adhesion of $S$. pneumoniae to respiratory epithelial cells 216 (Andersson et al., 1983). In order to test the anti-adhesion activity of selected wild berry 217 juice fractions and their subfractions against $S$. pneumoniae, human bronchial cells 218 (Calu-3) were chosen for the cell culture model (Elm et al., 2004). Cranberry juice FI 219 fraction inhibited the adhesion of S. pneumoniae to Calu-3 cells in a dose dependent 220 manner (Fig. 1A). The adhesion inhibition activity of cranberry juice was significant 221 and reached nearly $90 \%$ at the concentration of $8.7 \mathrm{mg} / \mathrm{g}(P<0.05)$. Activity decreased 222 towards lower concentrations and the lowest concentrations used $(2.3 \mathrm{mg} / \mathrm{g}$ and 1.7 $223 \mathrm{mg} / \mathrm{g}$ ) did not have an effect on pneumococcal adherence. Both bilberry and crowberry 224 juice FI (Fig. 1B, C) fractions possessed lower anti-adhesion activity (no dose225 dependent) compared to cranberry. Adhesion inhibition of both bilberry $(9 \mathrm{mg} / \mathrm{g})$ and 226 crowberry $(8.1 \mathrm{mg} / \mathrm{g})$ juice fractions was $52 \%$.

227 In our previous studies we found that $S$. pneumoniae bound to cranberry and bilberry 228 juice FI fractions in a microtiter well binding assay (Toivanen et al., 2010). Slight 229 adherence to crowberry juice FI fraction was also found. The concentrations of the 230 tested fractions in the assay employed ranged between $160-180 \mathrm{mg} / \mathrm{g}$. Due to 231 differences in the methodologies, in the present cell culture study anti-adhesion 232 activities were found even with 20-100 fold lower concentrations (1.6-9.0 mg/g). Our 233 current results thus support the earlier findings on pneumococcal binding to berry juice 234 FI fractions and gives further evidence on anti-adhesive properties of berry juices. 
235 Anti-adhesion activity of cranberry (Vaccinium macrocarpon Ait.) has been studied 236 widely in vitro against several bacteria (table 1). In vivo clinical trial has also been 237 carried out (Kontiokari et al., 2001). The anti-adhesive constituents in cranberry include 238 fructose (Zafriri et al., 1989), high molecular weight material (> $15 \mathrm{kDa}$ ) (Burger et al., 239 2000), and proanthocyanidins (Foo et al., 2000a; Foo et al., 2000b). In this study we 240 found adhesion inhibition against $S$. pneumoniae from low molecular size fractions of 241 cranberry, bilberry and crowberry juices $(<10 \mathrm{kDa})$. We have shown that FI fractions 242 contain only low-molecular-weight molecules, mainly sugar molecules and small 243 amounts of lower molecular weight phenolic compounds (Toivanen et al 2009; 244 Toivanen et al 2010). Carbohydrate receptors mediate the adhesion of S. pneumoniae to 245 respiratory epithelial cells and pneumococcal adherence can be blocked by 246 oligosaccharides (Bartehlson et al., 1998; Andersson et al., 1986) and by fractions of 247 milk (Andersson et al., 1986). In our previous microtiter well assay, pneumococcal 248 adherence to cranberry and bilberry juice FI fractions was not due to sugar molecules 249 (Toivanen et al., 2010). It is known that proanthocyanidins from cranberry juice can 250 prevent the adhesion of oligosaccharide $\alpha$-Gal $(1 \rightarrow 4) \beta-G a l$ recognizing adhesins in $E$.

251 coli (Foo et al.,2000a) and adhesion of Neisseria meningitidis pili can be blocked by 252 milk oligosaccharides (Hakkarainen et al., 2005) or by berry fractions containing 253 phenolic components (Toivanen et al., 2009). Here as well the phenolic compounds, 254 such as proanthocyanidins and anthocyanins of the berry juice fractions (Toivanen et 255 al., 2009), could be the active molecules against the pneumococcal adherence.

256 Anti-adhesion activity of the water subfractions prepared from the berry juice FI 257 fractions was also tested (Fig. 2). Adhesion inhibition achieved plateau in very low 258 concentrations of the subfractions $(1 \mu \mathrm{g} / \mathrm{mL}$ of cranberry, $5 \mu \mathrm{g} / \mathrm{mL}$ of bilberry, 15 
$259 \mu \mathrm{g} / \mathrm{mL}$ of crowberry). The best activity was found with cranberry and bilberry.

260 Cranberry juice subfraction inhibited significantly the pneumococcal adhesion at the

261 highest concentration tested $(50 \mu \mathrm{g} / \mathrm{mL})$; the adhesion inhibition was found to be $38 \%$

262 (Fig. 2A). As a comparison, potent anti-adhesion activity against E. coli was found from 263 ethyl acetate extracts of Sephadex LH20-purified cranberry proanthocyanidins at a 264 concentration of $75 \mu \mathrm{g} / \mathrm{mL}$ (Foo et al., 2000a). The adhesion inhibition activity of 265 bilberry with $50 \mu \mathrm{g} / \mathrm{mL}$ concentration was found to be $37 \%$ and it was not significant 266 (Fig. 2B). Crowberry had the lowest activity; anti-adhesion activity was $19 \%$ (50 $267 \mu \mathrm{g} / \mathrm{mL})($ Fig. 2C).

268 Subfractions were prepared from juice FI fractions by SPE subfractionation in order to 269 extract the active phenolic compounds from FI fractions (Toivanen et al., 2009; Sun et 270 al., 2006). Adhesion inhibition activity of the cranberry subfraction was significant, but 271 it was lower than adhesion inhibition caused by the cranberry FI fraction. The detected 272 reduction in activity of the F1 subfractions against the adhesion of $S$. pneumoniae may 273 result from loss of a combination of different phenolic molecules and/ or combination 274 with sugars or loss of a certain type of proanthocyanidins (Foo et al., 2000b; Määttä275 Riihinen et al., 2005) present in FI berry juice fractions and needed for the adhesion 276 inhibition. Detailed structural elucidation of the active phenolic molecules and the 277 possible combination of different molecules participating in the inhibition remains to be 278 carried out in future.

279 Antimicrobial Activity of Berry Juice FI Fractions and Subfractions against $S$. 280 pneumoniae. Berries and especially their polyphenols are known to inhibit the growth 281 of many human pathogens (Cavanagh et al., 2003; Matsushima et al., 2008; 282 Puupponen-Pimiä et al., 2005; Puupponen-Pimiä et al 2001). In the present study, 
283 cranberry, bilberry, and crowberry juice FI fractions were found to possess high 284 antimicrobial activity against S. pneumoniae (Fig. 3). The highest concentration used in 285 antimicrobial tests $(\sim 86 \mathrm{mg} / \mathrm{g})$ was extremely effective and the growth of $S$. pneumoniae 286 was inhibited totally by all FI fractions. At the concentration of $3.5 \mathrm{mg} / \mathrm{g}$ cranberry 287 juice fraction was still effective with nearly $100 \%$ growth inhibition, but for bilberry and crowberry juice fractions the bacterial survival was $60 \%$ and $39 \%$, respectively. At the lowest concentration tested $(1.7 \mathrm{mg} / \mathrm{g})$, the bacterial survival of all the berry juice FI fractions was found to be between 55-60\%. Subfractions did not have an effect on pneumococcal growth (data not shown). Bacterial survival was between 90-100 \% for 292 all subfraction concentrations, except for $50 \mu \mathrm{g} / \mathrm{mL}$ of bilberry juice subfraction (75\%). 293 Both anti-adhesion and antimicrobial effects were minor after subfractionation when compared to anti-adhesion and antimicrobial effects of the F1 berry juice fractions.

295 Our findings showed that small molecular size FI fractions from cranberry, bilberry, and crowberry juices had significant effect on growth of S. pneumoniae. In addition, cranberry juice FI fraction inhibited significantly binding of $S$. pneumoniae to human bronchial cells, while the FI fractions from bilberry and crowberry juices had a lower anti-adhesion effect. Compared to significant anti-adhesion activity of cranberry juice 300 FI fraction, the level of the anti-adhesion activity of the FI phenolic subfraction was substantially lower.

Here we examined adhesion inhibition in cell culture conditions by using excess amount of pneumococcal bacteria. The anti-adhesion activity was achieved with the cranberry juice FI fraction at the concentration of $8.7 \mathrm{mg} / \mathrm{g}$ of soluble solids, which contain small amount of polyphenols (Toivanen et al., 2009; Toivanen et al., 2010). The cranberry polyphenolic subfraction had inhibitory activity at the concentration of $5 \mathrm{mg} / 100 \mathrm{ml}$. 
307 The polyphenol concentration in cranberries is high, for example concentration of 308 proanthocyanidins is about $400 \mathrm{mg} / 100 \mathrm{~g}$ (Hellström et al., 2009). Thus in the 309 physiological conditions anti-adhesion may be achieved with reasonable amount of 310 cranberry juice. However, without in vivo trials it is difficult to estimate the inhibitory 311 effect and the amount of cranberry juice needed for the anti-adhesion.

312 In summary, these results indicate bilberry, crowberry, and especially cranberry juices 313 as novel sources for both anti-adhesive and antimicrobial agents against pneumococci. 314 Studies on molecular characterization of the active phenolic molecules remain to be 315 carried out in future. The studied berry juice FI fractions were solvent-free and water 316 soluble, thus their possible future utilization in food industry would be easy.

318 ACKNOWLEDGMENTS

319 We kindly thank Kiantama Ltd (Suomussalmi, Finland) and VIP-Juicemaker Ltd 320 (Kuopio, Finland) for providing berry juice samples, and Anu Ryynänen and Riikka 321 Sippola for subfractionation of the berry juice FI fractions. Sauli Haataja is appreciated 322 for providing the bacterial strain and Sari Ukkonen for excellent technical assistance. 


\section{REFERENCES}

324 Almirall J, Bolibar I, Serra-Prat M, Roig J, Hospital I, Carandell E, Agusti M, Ayuso P,

325 Estela A, Torres A, the Community-Acquired Pneumonia in Catalan Countries 326 (PACAP) Study Group. 2008. New evidence of risk factors for community-acquired 327 pneumonia: a population-based study. Eur Respir J 31: 1274-1284.

328 Amsterdam D. 2005. Susceptibility Testing of Antimicrobials in Liquid Media. In 329 Antibiotics in Laboratory Medicine, Loman V (ed). Lippincott Williams \& Wilkins: 330 Philadelphia, PA, USA; 61-143.

331 Andersson B, Dahmen J, Frejd T, Leffler H, Magnusson G, Noori G, Svanborg Eden C. 332 1983. Identification of an active disaccharide unit of a glycoconjugate receptor for 333 pneumococci attaching to human pharyngeal epithelial cells. J Exp Med 158: 559-570.

334 Andersson B, Porras O, Hanson LA, Lagergård T, Svanborg-Eden C. 1986. Inhibition 335 of attachment of Streptococcus pneumoniae and Haemophilus influenzae by human 336 milk and receptor oligosaccharides. J Infect Dis 153: 232-237.

337 Barthelson R, Mobasseri A, Zopf D, Simon P. 1998. Adherence of Streptococcus 338 pneumoniae to respiratory epithelial cells is inhibited by sialylated oligosaccharides. 339 Infect Immun 66: 1439-1444.

340 Bogaert D, de Groot R, Hermans PWM. 2004. Streptococcus pneumoniae colonisation: 341 the key to pneumococcal disease. Lancet Infect Dis 4: 144-154.

342 Burger O, Ofek I, Tabak M, Weiss EI, Sharon N, Neeman I. 2000. A high molecular 343 mass constituent of cranberry juice inhibits Helicobacter pylori adhesion to human 344 gastric mucus. FEMS Immunol Med Microbiol 29: 295-301. 
345 Cavanagh HMA, Hipwell M, Wilkinson JM. 2003. Antibacterial activity of berry fruits 346 used for culinary purposes. J Med Food 6: 57-61.

347 Elm C, Rohde M, Vaerman JP, Chhatwal GS, Hammerschmidt S. 2004. 348 Characterization of the interaction of the pneumococcal surface protein SpsA with the 349 human polymeric immunoglobulin receptor (hpIgR). Indian J Med Res 119: 61-65.

350 Feldman C, Anderson R. 2009. New insights into pneumococcal disease. Respirology 351 14: 167-179.

352 Foo LY, Lu Y, Howell AB, Vorsa N. 2000a. The structure of cranberry 353 proanthocyanidins which inhibit the adherence of uropathogenic P-fimbriated 354 Escherichia coli in vitro. Phytochemistry 54: 173-181.

355 Foo LY, Lu Y, Howell AB, Vorsa N. 2000b. A-type proanthocyanidin trimers from 356 cranberry that inhibit adherence of uropathogenic P-fimbriated Escherichia coli. J Nat 357 Prod 63: 1225-1228.

358 Hakkarainen J, Toivanen M, Leinonen A, Frängsmyr L, Strömberg N, Lapinjoki S, 359 Nassif X, Tikkanen-Kaukanen C. 2005. Human and bovine milk oligosaccharides 360 inhibit Neisseria meningitidis pili attachment in vitro. J Nutr 135: 2445-2448.

361 Hellström J, Törrönen R, Mattila P. Proanthocyanidins in common food products of 362 plant origin. 2009. J Agric Food Chem 57: 7899-7906.

363 Howell AB, Vorsa N, Marderosian AD, Foo LY. 1998. Inhibition of the adherence of P364 fimbriated Escherichia coli to uroepithelial-cell surfaces by proanthocyanidin extracts 365 from cranberries. N Engl J Med 339: 1085-1086. 
366 Idänpään-Heikkilä I, Simon PM, Zopf D, Vullo T, Cahill P, Sokol K, Tuomanen E. 367 1997. Oligosaccharides interfere with the establishment and progression of 368 experimental pneumococcal pneumonia. J Infect Dis 176: 704-712.

369 Joosten JAF, Loimaranta V, Appeldoorn CCM, Haataja S, El Maate FA, Liskamp RMJ, 370 Finne J, Pieters RJ. 2004. Inhibition of Streptococcus suis adhesion by dendritic 371 galabiose compounds at low nanomolar concentration. J Med Chem 47: 6499-6508.

372 Kadioglu A, Weiser JN, Paton JC, Andrew PW. 2008. The role of Streptococcus 373 pneumoniae virulence factors in host respiratory colonization and disease. Nat Rev $374 \quad$ Microbiol 6: 288-301.

375 King T, Dykes G, Kristianti R. 2008. Comparative evaluation of methods commonly 376 used to determine antimicrobial susceptibility to plant extracts and phenolic compounds. $377 \quad J$ AOAC Int 91: 1423-1429.

378 Kontiokari T, Sundqvist K, Nuutinen M, Pokka T, Koskela M, Uhari M. 2001. 379 Randomized trial of cranberry-lingonberry juice and Lactobacillus GG drink for the 380 prevention of the urinary tract infections in women. BMJ 332: 1571-1575.

381 Matsushima M, Suzuki T, Masui A, Kasai K, Kouchi T, Tagaki A, Shirai T, Mine T. 382 2008. Growth inhibitory action of cranberry on Helicobacter pylori. J Gastroenterol 383 Hepatol 23: S175-80.

384 Mitchell TJ. 2003. The pathogenesis of streptococcal infections: from tooth decay to 385 meningitis. Nat Rev Microbiol 1: 219-230. 
386 Määttä-Riihinen KR, Kähkönen MP, Törrönen RA, Heinonen MI. 2005. Cathecins and 387 procyanidins in berries of Vaccinium species and their antioxidant activity. J Agric 388 Food Chem 53: 8485-8491.

389 Ofek I, Hasty DL, Sharon N. 2003. Anti-adhesion therapy of bacterial diseases: 390 prospects and problems. FEMS Immunol Med Microbiol 38: 181-191.

391 Puupponen-Pimiä R, Nohynek L, Hartmann-Schmidlin S, Kähkönen M, Heinonen M, 392 Määttä-Riihinen K, Oksman-Caldentey KM. 2005. Berry phenolics selectively inhibit 393 the growth of intestinal pathogens. J Appl Microbiol 98: 991-1000.

394 Puupponen-Pimiä R, Nohynek L, Meier C, Kähkönen M, Heinonen M, Hopia A, 395 Oksman-Caldentey KM. 2001. Antimicrobial properties of phenolic compounds from 396 berries. J Appl Microbiol 90: 494-507.

397 Rytkönen A, Albiger B, Hansson-Palo P, Källström H, Olcen P, Fredlund H, Jonsson 398 AB. 2004. Neisseria meningitidis undergoes PilC phase variation and PilE sequence 399 variation during invasive disease. J Infect Dis 189: 402-409.

400 Sun B, Leandro MC, de Freitas V, Spranger MI. 2006. Fractionation of red wine 401 polyphenols by solid-phase extraction and liquid chromatography. J Chromatog., A 402 1128: 27-38.

403 Todoriki K, Mukai T, Sato S, Toba T. 2001. Inhibition of adhesion of food-borne 404 pathogens to Caco-2 cells by Lactobacillus strains. J Appl Microbiol 91: 154-159.

405 Toivanen M, Ryynänen A, Huttunen S, Duricova J, Riihinen K, Törrönen R, Lapinjoki 406 S, Tikkanen-Kaukanen C. 2009. Binding of Neisseria meningitidis pili to berry 407 polyphenolic fractions. J Agric Food Chem 57: 3120-3127. 
408 Toivanen M, Huttunen S, Duricova J, Soininen P, Laatikainen R, Loimaranta V, 409 Haataja S, Finne J, Lapinjoki S, Tikkanen-Kaukanen, C. 2010. Screening of binding 410 activity of Streptococcus pneumoniae, Streptococcus agalactiae and Streptococcus suis 411 to berries and juices. Phytother Res 24: S95-S101.

412 Weiser JN, Austrian R, Sreenivasan PK, Masure HR. 1994. Phase variation in 413 pneumococcal opacity: relationship between colonial morphology and nasopharyngeal 414 colonization. Infect Immun 62: 2582-2589.

415 Weiss EI, Lev-Dor R, Sharon N, Ofek I. 2002. Inhibitory effect of a high-molecular416 weight constituent of cranberry on adhesion of oral bacteria. Crit Rev Food Sci Nutr 42: $417 \quad 285-292$.

418 Woodhead M, Blasi F, Ewig S, Huchon G, Leven M, Ortqvist A, Schaberg T, Torres A, 419 van der Heijden G, Verheij TJM. 2005. Guidelines for the management of adult lower 420 respiratory tract infections. Eur Respir J 26: 1138-1180.

421 Zafriri D, Ofek I, Adar R, Pocino M, Sharon N. 1989. Inhibitory activity of cranberry 422 juice on adherence of type 1 and type P fimbriated Escherichia coli to eukaryotic cells. 423 Antimicrob Agents Chemother 33: 92-98.

424 Zopf D, Roth S. 1996. Oligosaccharide anti-infective agents. Lancet 347: 1017-1021. 
425 Table 1. In vitro and in vivo anti-adhesion activity of cranberry (Vaccinium 426 macrocarpon Ait.)

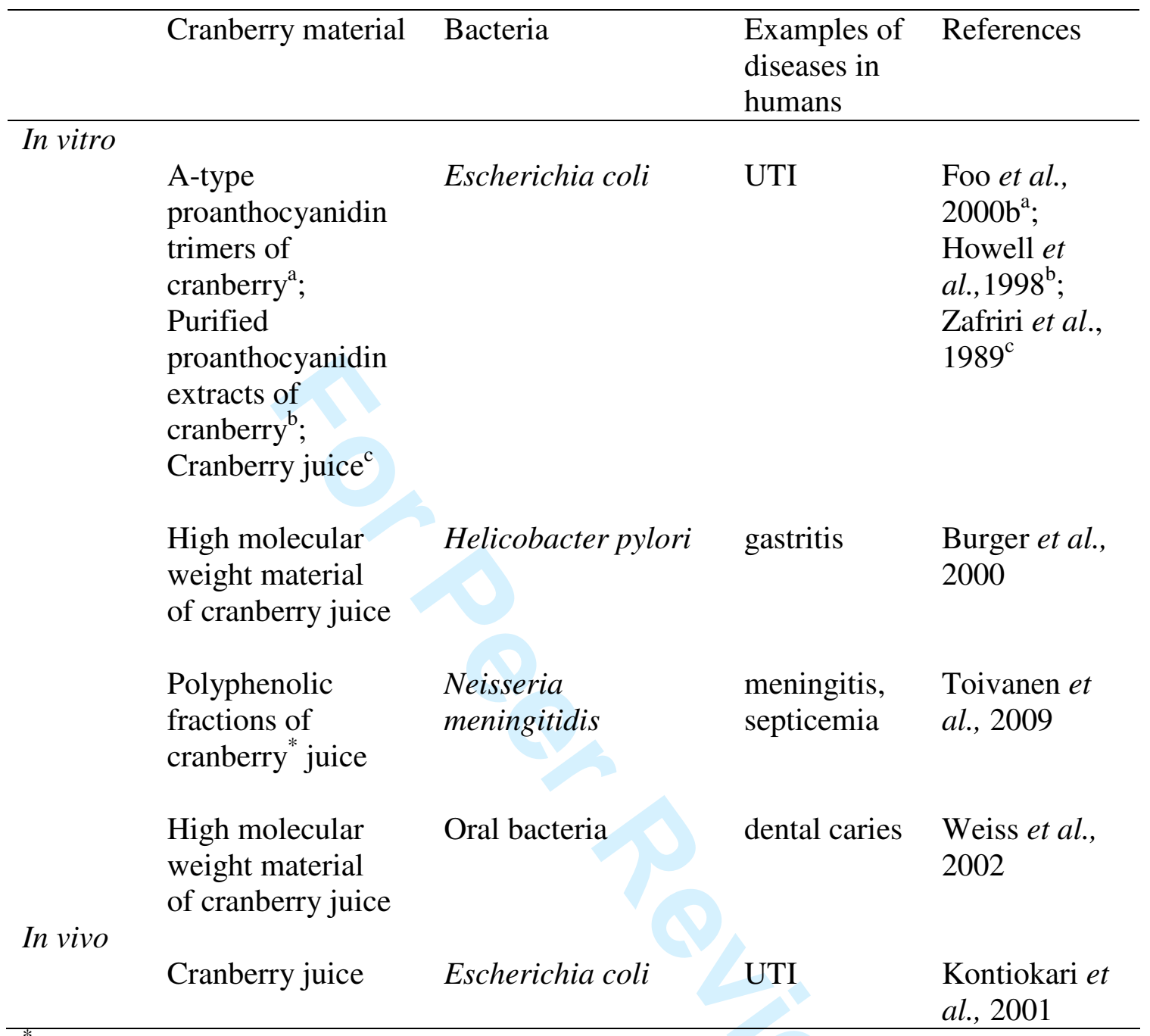

"Vaccinium oxycoccos L.; UTI, urinary tract infection 


\section{FIGURE LEGENDS}

429 Figure 1. Inhibition of adhesion (mean $\pm \mathrm{SEM}, n=6$ ) of $S$. pneumoniae to Calu-3 430 human bronchial epithelial cell line by fraction F1 $(<10 \mathrm{kDa})$ of $\mathbf{A})$ cranberry juice, $\mathbf{B})$ 431 bilberry juice, and C) crowberry juice. Inhibition of adhesion expressed as the 432 percentage of bacterial control. Apple juice fraction F1 with constant concentration 11 $433 \mathrm{mg} / \mathrm{g}$ was used as negative control (dotted line). $* P<0.05$ against the bacterial control.

435 Figure 2. Inhibition of adhesion (mean $\pm \mathrm{SEM}, n=6$ ) of $S$. pneumoniae to Calu-3 436 human bronchial epithelial cell line by berry juice subfractions of A) cranberry juice, B) 437 bilberry juice, and C) crowberry juice. Inhibition of adhesion expressed as the 438 percentage of bacterial control. Apple juice FI fraction with constant concentration 11 $439 \mathrm{mg} / \mathrm{g}$ was used as negative control (dotted line). $* P<0.05$ against the bacterial control.

441 Figure 3. Antimicrobial activity of FI berry juice fractions $(<10 \mathrm{kDa})$ of cranberry, 442 bilberry, and crowberry. Bacterial survival compared to control, mean \pm SEM of three 443 experiments. Bacterial survival with Ampicillin $(100 \mu \mathrm{g} / \mathrm{mL})$ was $5 \%$. $* P<0.05$ 444 against the bacterial control. 
Huttunen S, Figure 1.
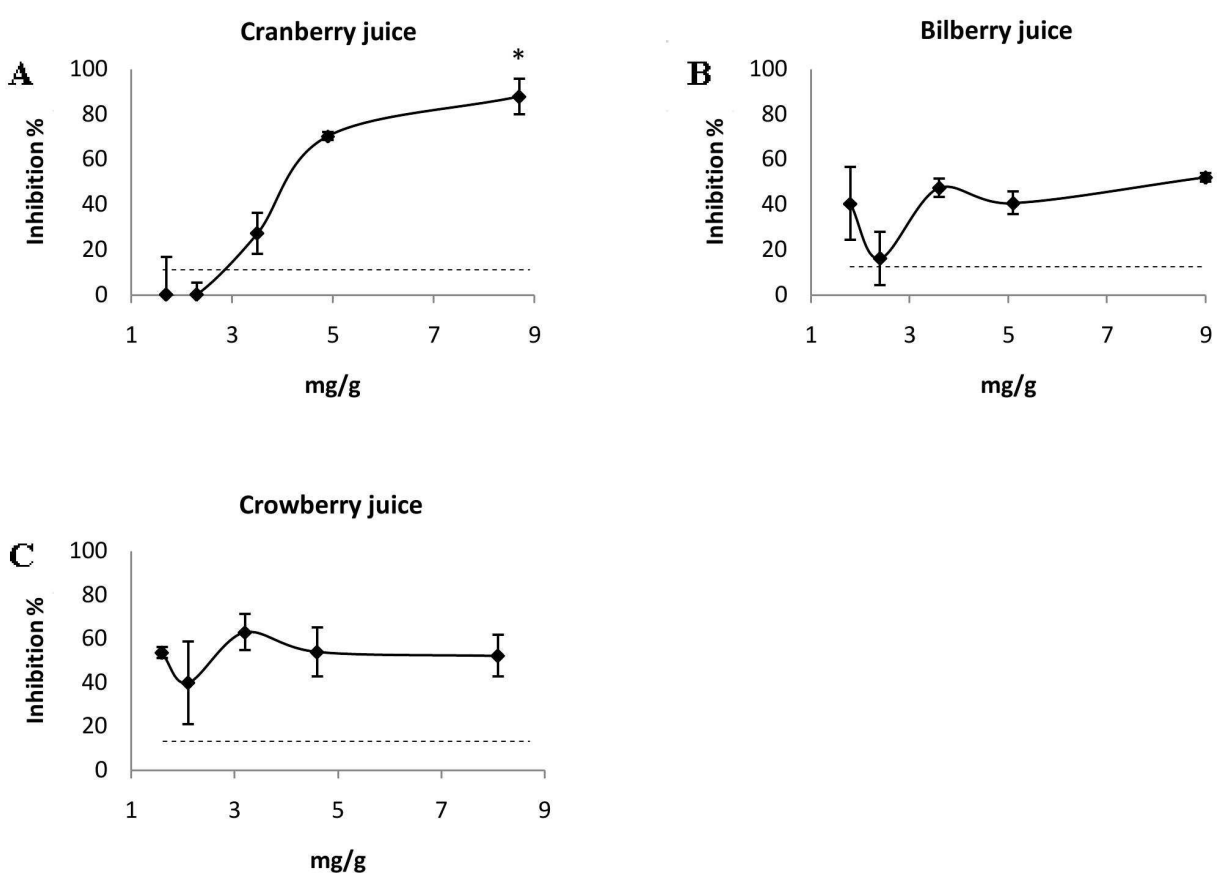

$180 \times 143 \mathrm{~mm}(300 \times 300$ DPI) 
1

2

3

4

5

6

7

8

9

10

11

12

13

14

15

16

17

18

19

20

21

22

23

24

25

26

27

28

29

30

31

32

33

34

35

36

37

38

39

40

41

42

43

44

45

46

47

48

49

50

51

52

53

54

55

56

57

58

59

60
Huttunen S, Figure 2.
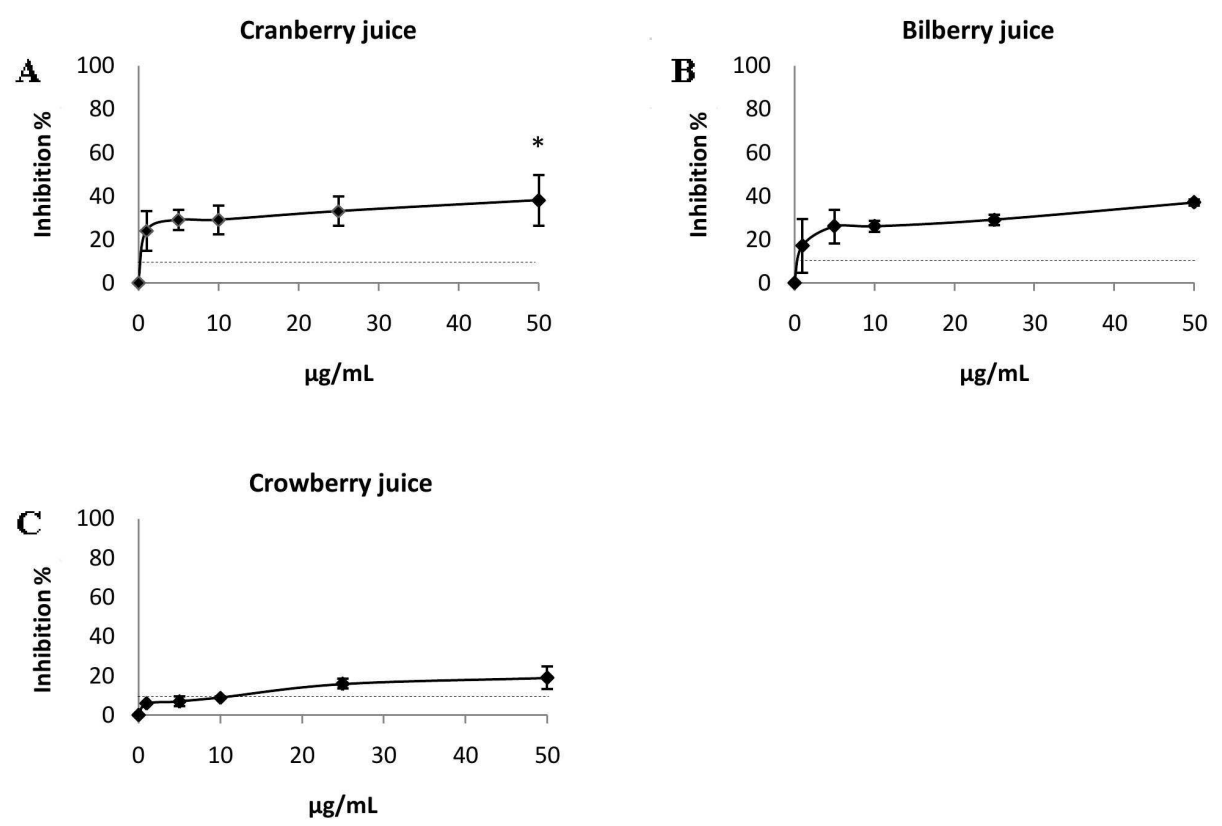

$180 \times 143 \mathrm{~mm}(300 \times 300$ DPI $)$ 


\section{Huttunen S, Figure 3}

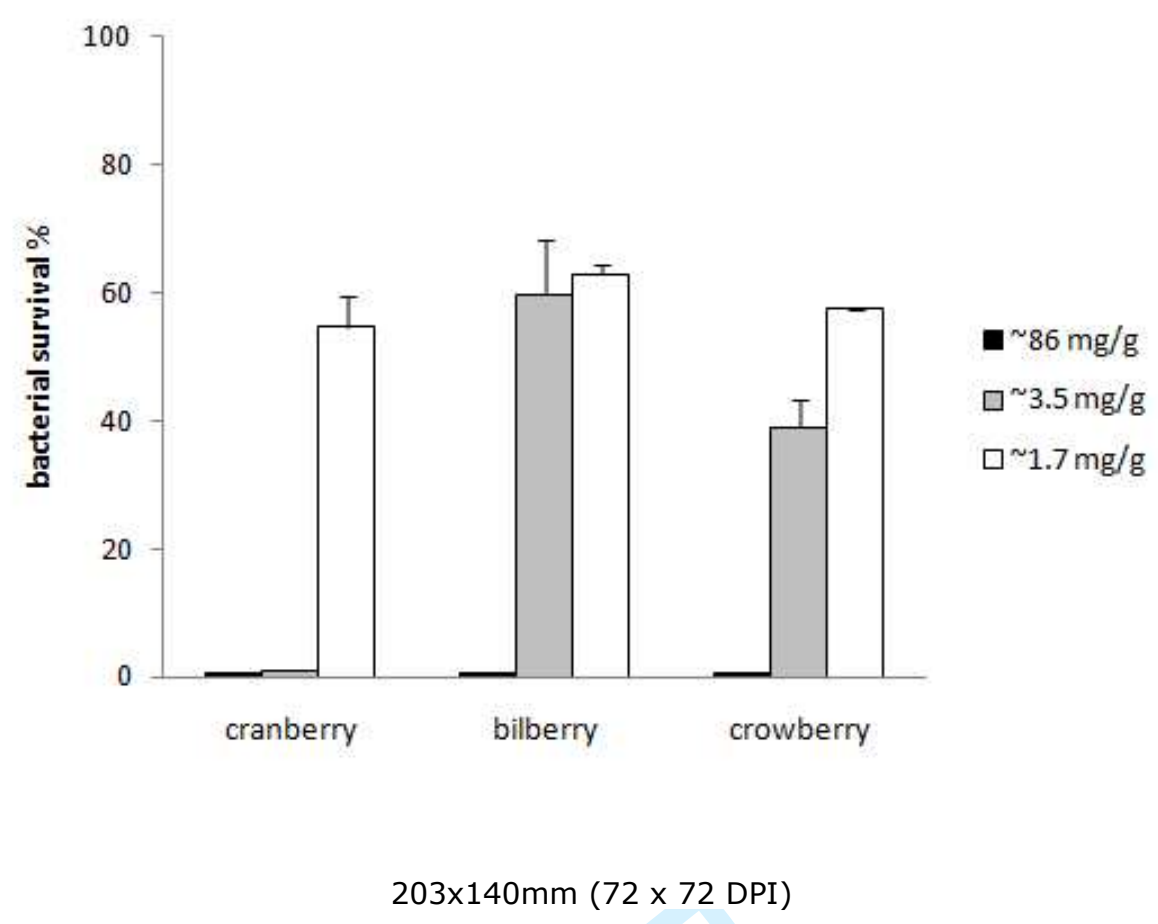

32

33

34

35

36

37

38

39

40

41

42

43

44

45

46

47

48

49

50

51

52

53

54

55

56

57

58

59

60

http://mc.manuscriptcentral.com/ptr 